\title{
An Identification of Students' Responses Towards the Implementation of Biological Learning to Answer the Challenges of Educators in The Industrial Revolution 4.0 Era
}

\author{
Indah Dewi Sartika ${ }^{1, *}$ Linda Advinda ${ }^{1}$
}

\author{
${ }^{1}$ Biology Department, Math and Natural Science Faculty, Universitas Negeri Padang, Padang, Indonesia \\ *Corresponding author. Email: sartika.indahdewi@yahoo.co.id
}

\begin{abstract}
Changes in the world are now entering the era of industrial revolution 4.0 (IR 4.0) where information technology has become the basis in human life. Based on the initial evaluation, Indonesia is estimated as a country with high potential in facing IR 4.0. Nevertheless, education 4.0 is a response to the needs of IR 4.0. One of the challenges of educators in the IR 4.0 era was being able to innovate creatively in the implementation of learning. This study aims at identifying students' responses to the implementation of Bilogical learning. The subjects of this study consisted of 30 students of XI MIPA 7 Class of SMAN 1 Pariaman. Based on the results of the study, there were $73.33 \%$ of the students who were happy if the teacher did not come; $69.16 \%$ of the students had difficulty understanding the material taught by the teachers; only $27.50 \%$ of the students agreed if the teacher only used the lecturing method in teaching. The low innovation and creativity of the teachers in designing learning resulted in low interest in learning that would have an impact on student learning outcomes. Therefore, the identification of the students' responses to the implementation of biological learning was done to answer the challenges of educators in the industrial revolution 4.0 era.
\end{abstract}

Keywords: Education 4.0, Student responses, Innovation, Implementation of learning

\section{INTRODUCTION}

Changes in the world are entering the era of industrial revolution 4.0 (IR 4.0) where information technology has become the basis in human life [1]. The term industry 4.0 comes from a project initiated by the German government to promote computerized manufacturing called the HighTech Strategy 2020 [2,3].

The fourth industrial revolution is the development of the 3rd industrial revolution, in which the revolution is based on cyber physical systems, a combination of digital, physical and biological domains [4,5,6]. Based on the initial evaluation, Indonesia was estimated as a country with high potential in dealing with IR 4.0 [7].

Education 4.0 is a response to the needs of IR 4.0 [8]. The challenges of educators in the IR 4.0 era: first, knowing digital usage and applying it; second, leadership competence that directs students to have technological knowledge; third, having the ability to predict precisely the direction of the turmoil of change and strategic steps to deal with it; fourth, having competence in controlling themselves from all the turmoil of change, and are able to deal with it by generating ideas, innovations, and having creativity [9]. Therefore, educators are required to be more innovative and creative in designing the implementation of learning.

In facing the IR 4.0 era, several things must be prepared including: a) preparation of a more innovative learning system to produce competitive and skilled graduates, especially in the aspects of data literacy, technological literacy and human literacy; b) reconstruction of higher education institutional policies that are adaptive and responsive to IR 4.0 in developing the trans disciplinary knowledge and study programs needed; c) Preparation of responsive, adaptive and reliable human resources to deal with IR 4.0; d) rejuvenation of infrastructure and development of education, research and innovation infrastructure also needs to be done to sustain the quality of education, research, and innovation [10].

The 2013 curriculum focuses on character education goals that are formulated not only in terms of cognitive, but also affective and psychomotor that are expected to develop abilities in (1) solving problems, (2) critical thinking, (3) innovative and (4) entrepreneurs to compete in the world of work or globally and is able to present the knowledge gained from learning material $[11,12,13,14]$.

In 2009, PISA published the results of a survey which showed that from 65 countries, based on reading ability, Indonesia ranked 57th with a score of 402, mathematical ability ranked 61 st with a score of 371 , and IPA ability ranked 60th with a score of 383 [15]. In addition, the 
results of the 2010 Education for All (EFA) Global Monitoring Report released by UNESCO assessed that Indonesia's Education Development Index (EDI) ranked 65 th out of 128 countries with an EDI of 0.947 with the secondary education development index category [16], and Indonesia's EDI ranking dropped further in 2011 to 69th out of 127 countries surveyed with an EDI value of 0.934 [17]. One reason is the low ability of innovation and creativity of educators in developing learning methods and models that are able to improve aspects of data literacy, technological literacy and human literacy.

SMA Negeri 1 Pariaman is one of the schools that has implemented the 2013 Curriculum. In order to answer the low EDI ranks, the identification of students' responses to the implementation of biological learning was conducted. This information is important to enhance the creativity and innovation of educators in determining models and methods in implementing learning to be carried out. Therefore, this study carried out the identification of Students' Responses Towards the Implementation of Biological Learning to answer the Challenges of Educators in the Industrial Revolution 4.0 Era.

\section{METHODS}

This study was a descriptive research. Descriptive research is a form of research aimed at describing phenomena that exist, both natural phenomena and man-made phenomena [18]. The subjects of this study consisted of 30 students of XI MIPA 7 class of SMAN 1 Pariaman. The instruments used in this study were interview sheets and questionnaires. The analysis of the data in this study was by using descriptive statistical analysis techniques.

\section{Questioner}

Student responses can be analyzed by calculating the average overall score that has been made with a Likert scale model. Under the Likert category scale, answers are weighted or equated with quantitative values $4,3,2,1$ for positive questions and 1, 2, 3, 4 for questions that are negative ${ }^{[19]}$. The Likert scale model uses the following formula:

ResponseValue $=\frac{\text { Itemobtained score }}{\text { maximLm.score }} \times 100 \%$

The results obtained are confirmed with the following criteria ${ }^{[20]}$ :

Table 1. Classification of assessment of students' responses to biology subjects.

\begin{tabular}{|c|c|}
\hline Response Value (\%) & Criteria \\
\hline $80-100$ & Very good \\
\hline $66-79$ & good \\
\hline $56-65$ & Pretty good \\
\hline $40-55$ & Not good \\
\hline $0-39$ & Very bad \\
\hline
\end{tabular}

Table 2. Classification of assessment of students' responses to the implementation of learning biology.

\begin{tabular}{|c|c|}
\hline Response Value (\%) & Criteria \\
\hline $80-100$ & Strongly agree \\
\hline $66-79$ & agree \\
\hline $56-65$ & Quite agree \\
\hline $40-55$ & not agree \\
\hline $0-39$ & Strongly Disagree \\
\hline
\end{tabular}

\section{RESULT AND DISCUSSION}

Table 3. Student responses to biology subjects.

\begin{tabular}{|l|c|c|}
\hline \multicolumn{1}{|c|}{ Question } & $\begin{array}{c}\text { Response } \\
\text { Value (\%) }\end{array}$ & Criteria \\
\hline $\begin{array}{l}\text { I always pay attention to biology lessons } \\
\text { explained by the teacher }\end{array}$ & $61,66 \%$ & $\begin{array}{l}\text { Quite } \\
\text { Agree }\end{array}$ \\
\hline $\begin{array}{l}\text { I am not reluctant to ask the teacher if } \\
\text { there is material in biology that I do not } \\
\text { understand }\end{array}$ & $62,50 \%$ & $\begin{array}{c}\text { Quite } \\
\text { Agree }\end{array}$ \\
\hline $\begin{array}{l}\text { I'm happy if the biology teacher doesn't } \\
\text { come }\end{array}$ & $73,33 \%$ & Agree \\
\hline $\begin{array}{l}\text { When the teacher explained the biology } \\
\text { subject, I was lazy to pay attention } \\
\text { seriously }\end{array}$ & $66,66 \%$ & $\begin{array}{l}\text { Quite } \\
\text { Agree }\end{array}$ \\
\hline $\begin{array}{l}\text { I always work on biology assignments } \\
\text { given by the teacher with pleasure }\end{array}$ & $69,16 \%$ & Agree \\
\hline $\begin{array}{l}\text { I find it difficult to understand the } \\
\text { biological material taught by the teacher }\end{array}$ & $69,16 \%$ & Agree \\
\hline $\begin{array}{l}\text { I am happy if the teacher always explains } \\
\text { learning by the lecture method }\end{array}$ & $27,50 \%$ & $\begin{array}{l}\text { Strongly } \\
\text { Disagree }\end{array}$ \\
\hline
\end{tabular}


Based on the results of the study, it showed that the students were confident enough and active in asking questions if there was subject matter that was not understood with a response result of $62.50 \%$. In addition, $69.16 \%$ of the students were classified as diligent students in terms of understanding the tasks given by the teacher. $73.33 \%$ of the students were happy if the biology teacher did not come. $61.66 \%$ of the students always pay attention to biology learning material explained by the teacher. Although they always pay attention, $66.66 \%$ of the students were quite lazy to pay attention to the lesson seriously. Then, $27.50 \%$ of the students were happy if the teacher explained the lesson with the lecturing method and the rest were not happy with the method.

The students' responses in general to biological learning were good. The students did not hesitate to ask the teacher if there was material that was not understood and always did the work given by the teacher. However, the students have difficulty in understanding the material taught by the teacher because teachers generally used the lecturing method in teaching. The results of interviews with biology teachers at SMAN 1 Pariaman, Ms. Murniwati and Ms. Masyhuda generally applied the lecturing method in implementing learning. The lecturing method applied by the teacher caused the interest in learning to be low so that it gave impacts on the low learning outcomes.

Learning difficulties is a condition in which students cannot learn naturally, due to threats, obstacles, or disruptions in learning. Learning difficulties of students will be evident from the decline in learning achievement obtained ${ }^{[21]}$. Potentially, the students have the ability to have better achievements, but the implementation of learning that is not appropriate results in not achieving the objectives of learning. Based on Umiyati's research, learning achievement is influenced by external and internal factors ${ }^{[23,24]}$, the percentage of external factors that cause learning difficulties of the students of X6 class; one of

which is a teaching method with a percentage of $27.76 \%$, which will trigger internal factors, one of which is interest in learning with a percentage of $50.35 \%{ }^{[22]}$.

The lecturing method applied by the teacher as the information provider (teacher centered) makes the teacher the authority in learning, thus limiting the involvement of students in learning. Interest means a tendency and a great desire for something ${ }^{[25]}$. Students' interest in the lesson can be seen from the tendency to give greater attention to the lesson. For students with high learning interest, the lecturing method will limit the activities of students in developing learning so that it impacts on the lack of mastery of scientific concepts and attitudes ${ }^{[26]}$.

Therefore, to face the challenges in the IR 4.0 era educators are expected to be able to utilize the use of technology ${ }^{[9]}$ in designing more innovative and creative learning practices ${ }^{[10]}$, so as to be able to increase students' learning interest. Because high interest in learning tends to result in high achievement, conversely less interest in learning will result in low learning achievement ${ }^{[27]}$.

\section{CONCLUSION}

Students' responses in general to the biological learning are good. Learners do not hesitate to ask the teacher if there is material that is not understood and always do the work given by the teacher. However, the students have difficulty in understanding the material taught by the teacher because the teacher generally use the lecturing method in teaching. The lecturing method applied by the teacher makes the students passive and decreased interest in learning so that the impact on low learning outcomes.

\section{REFERENCES}

[1] Kemristekdikti. 2018. Pengembangan Iptek dan Pendidikan Tinggi di Era evolusilndustri 4.0. (Online),(https://www.ristekdikti.go.id/pengembangani ptek-dan-pendidikan- tinggi-di-era-revolusi-industri-40/diakses 21 July 2019)

[2] Yahya, M. 2018. Era Industri 4.0: Tantangan Dan Peluang Perkembangan Pendidikan Kejuruan Indonesia. Disampaikan pada Sidang Terbuka Luar Biasa Senat Universitas Negeri Makassar, 14 Maret 2018

[3] Heng, S. 2014. Industry 4.0: Upgrading of Germany's Industrial Capabilities on the Horizon. (https://ssrn.com/abstract=2656608, diakses pada 21 July2019)

[4] Schwab, K. (2017). The fourth industrial revolution. Crown Business Press.

[5] Pannen, P. 2018. Mempersiapkan SDM Indonesia di Era Industri 4.0. Kementerian Riset, Teknologi dan Pendidikan Tinggi

[6] Thai, H. V dan Anh, M. A. L. T. K. 2017. The 4.0 Industrial Revolution Affecting Higher Education Organizations' Operation In Vietnam. International Journal of Management Technology. Vol.4, No 2, pp. $1-12$

[7] Ghiffar, M. A. N., Nurisma, E., Kurniasih, C dan Bhakti, C. P. 2018. Model Pembelajaran Berbasis Blended Learning Dalam Meningkatkan Critical Thinking Skills Untuk Menghadapi Era Revolusi Industri 4.0. Prosiding Seminar Nasional Pendidikan, $85-94$

[8] Hussin, A. A. 2018. Education 4.0 Made Simple: Ideas For Teaching. International Journal of Education \& Literacy Studies, 6 (3): 92-98 
[9] Mintasih, D. 2018. Mengembangkan Literasi Informasi Melalui Belajar Berbasis Kehidupan Terintegrasi Pbl Untuk Menyiapkan Calon Pendidik Dalam Menghadapi Era Revolusi Industri 4.0. ELEMENTARY: Islamic Teacher Journal Vol. 6 (2): 271-290

[10] Menristekdikti. 2018. Pengembangan Iptek dan Pendidikan Tinggi di Era Revolusi Industri 4.0. (Online), (https://www.ristekdikti.go.id/siaranpers/pengembangan-iptek-dan-pendidikan-tinggi-diera-revolusi-industri-4-0/ diakses 21 July2019)

[11] Maemunah. 2018. Kebijakan Pendidikan Pada Era Revolusi Industri 4.0 Prosiding Seminar NasionalLembaga Penelitian dan Pendidikan (LPP) Mandala, 1-9

[12] Sari, R. H. 2017. Pengaruh Implementasi Pembelajaran Stem Terhadap Persepsi, Sikap, dan Kreativitas Siswa. Prosiding Seminar Nasional MIPA III, 416-420

[13]Utomo, A. P., Prijatin, J dan Pujiastuti. 2014. Pengembangan Bahan Ajar IPA Berbasis Pendekatan Sains Teknologi Masyarakat (STM) Pada Pokok Bahasan Limbah dan Penanganannya Kelas XI Sekolah Menengah Kejuruan (SMK). Pancaran, 3 (4): 163-174

[14] Kanematsu, H., \& Barry, D. M. 2016. STEM and ICT Education in Intelligent Environments. London: Springer International Publishing Switzerland

[15] OECD. 2012.PISA 2009 Technical Report. PISA: OECD Publishing. (Online), (www.pisa.oecd.org/ diaskes 21 July 2019)

[16] EFA. 2010. "Education for All Global Monitoring Report 2010, UNESCO(Online), (www.unesco.org/ diakses 21 July 2019)

[17] EFA. 2011. "Education for All Global Monitoring Report 2010”.

UNESCO(Online),(www.unesco.org/ diunduh 21 July2019)

[18] Sukmadinata, N. S. 2006. Metode Penelitian Tindakan. Bandung :Remaja Rosda Karya

[19] Sukardi. 2004. Metodologi Penelitian; Kompetensi dan Prakteknya. Jakarta: Bumi Aksara

[20] Sudjana, N. 2005. Pengantar Statistik Pendidikan. Jakarta: Raja Grapindo Persada
[21] Djamarah, S. B. 2011. Psikologi Belajar. Jakarta: Rineka Cipta

[22] Umiyati, D., dan Susilo, M. J. 2014. Perbandingan Faktor-Faktor Penyebab Kesulitan Belajar antaraSiswa Kelas X.6 dengan Kelas X.7 pada Mata Pelajaran Biologi Materi Virus (Study Kasus di SMA N 1 Sukagumiwang - Indramayu). JUPEMASIPBIO, 1(1):106-108

[23] Ahmadi, A dan Supriyono, W. 2004. Psikologi Belajar. Jakarta: Rineka Cipta

[24] Jamal, F. 2014. Analisis Kesulitan Belajar Siswa Dalam Mata Pelajaran Matematika Pada Materi Peluang Kelas XI IPA Sma Muhammadiyah Meulaboh Johan Pahlawan. Jurnal MAJU (Jurnal Pendidikan Matematika), 1(1):18 - 36

[25] Syah, M. 2003. Psikologi Pendidikan dengan Pendekatan Baru. Bandung: Remaja Rosdakarya

[26] Siagian, R. E. F. 2011. Pengaruh Minat dan Kebiasaan Belajar Siswa Terhadap Prestasi Belajar Matematika. Jurnal Formatif, 2(2): 122-131

[27] Djamarah, S. B.2002. Strategi Belajar Mengajar. Jakarta: Rineka Cipta 